\title{
Critique of decentralized political structures in water resource management in Tanzania: the case of Pangani river basin
}

\author{
T. R. Olemako ${ }^{1}$, P. K. T. Munishi ${ }^{2} \&$ R. M. J. Kadigi ${ }^{3}$ \\ ${ }^{1}$ Development Studies Institute, Sokoine University of Agriculture, \\ Tanzania \\ ${ }^{2}$ Faculty of Forestry and Nature Conservation, \\ Department of Forest Biology, Sokoine University of Agriculture, \\ Tanzania \\ ${ }^{3}$ Faculty of Agriculture, Department of Agriculture Economics and \\ Agribusiness, Sokoine University of Agriculture, Tanzania
}

\begin{abstract}
Tanzania adopted the river basin model in 1950s and declared it as an essential feature for economic development. Since 1990 management of water resources in Tanzania is based on the nine river basins that do not follow administrative boundaries as defined under the system of decentralized political structures. Water is a key resource in the river basin; however, it is not a driver of economic development. Drivers of economic development are outside the water sector such as energy, agriculture and mining. The non-water sectors fall under decentralized political structures from the central government ministries, regional administration to local government authorities. The system of political structures cut across different varieties of governance from central to local government levels. Variance in governance under these structures has intensified water scarcity and as an institutional and legal tool is more rhetorical rather than practical. Total water withdrawal in Tanzania is estimated to be 5,142 million $\mathrm{m}^{3}$ out of which agriculture development consumes more than $85 \%$ and the rest accounts for the domestic sector, livestock development and industry. Water scarcity hinders the effectiveness of the adopted river basin model as competition of water use between hydropower production and irrigation is intense. This paper addresses the main questions as to what effects
\end{abstract}


these structures have on institutional policy design and discourse in the river basin management. Do the structures promote or block institutional reforms? How is the sustainability of the reforms ensured? This paper suggests a mainstream institutional set up of a non-water sector into the river basin model from the central to local government levels.

Keywords: political structures, decentralization, institutions, Tanzania, Pangani, river basin, water scarcity.

\section{Introduction}

The objective of this paper is to examine the level of dependence by stakeholders from wetlands of Pangani river basin and its contribution to economic development. Wetlands are becoming one of the key environmental conflict areas in many parts of Eastern Africa (Kamukala [4]; Southgate and Hulme [20]; Dixon and Wood [2]). The major source of conflicts experienced in the wetland communities is a result of water scarcity due to lack of elaborate institutional framework to facilitate the integration of the various sectoral and cross sectoral uses of wetland resources among stakeholders (Kangalawe and Liwenga [6]). Wetlands cover about $6 \%$ of the earth surface out of which $88 \%$ is occupied by wetlands in freshwater environments (Ramsar [18]). Wetlands in Tanzania cover $10 \%$ of the total land area, of which $5.5 \%$ is presently for four Ramsar sites (URT [27]). Wetland components include water, vegetation (flora), animals (fauna) and soil. This study is focusing on water as one component of wetlands and how this resource is managed and valued by different stakeholders within the decentralized system of political structures.

According to URT [24] the concept of river basin was introduced as a present management system in the water sector of allocating water based on hydrological boundaries. As noted by World Bank [29] water scarcity in Tanzania became a national issue in early 1990 and administration of water resources under river basins was meant to address the situation. Since 1990 management of water resources in Tanzania was entirely based on the nine river basins that do not follow administrative boundaries as defined under the system of decentralized political structures. Water is a controlling factor and a key resource in the river basin however is not a driver of economic development. Drivers of economic development are from non-water sectors such as agriculture, fisheries, livestock, energy, mining and do provide varied livelihood options in wetland communities of Pangani. However Lein and Tagseth [8] questioned on how practical can a river basin model be applicable within political and administrative boundaries and as concluded by Barham [1] in Lein and Tagseth [8] adoption of the model will definitely lead to conflicts with democratic rights.

Variance in governance between water and non-water sectors has contributed to water scarcity and conflicts in wetlands of Pangani. Water scarcity hinders the effectiveness of the adopted river basin model as competition of water use between hydropower production and irrigation is critical. Water is not seen as a resource to facilitate economic development but rather for revenue generation. These authors note that, almost $90 \%$ of the surface flow water in Pangani is used 
for irrigation and hydropower production and the main conflicts which exist are between upstream and downstream users (Mujwahuzi [10]; Mbonile et al. [9]; Turpie et al. [21]; PBWO/IUCN [14]). On attempt to implement strategies under the National Strategy for Growth and Reduction of Poverty (NSGRP/MKUKUTA) since 1996 the Prime Minister's Office - Regional Administration and Local Government (PMO-RALG) undertook major reforms within local government authorities and among many was the critical issue of governance. However the reforms did not unpack governance issues within and between sectors and leave a lot to be desired. Governance problems as outlined by PMO-RALG [16] originate from three categories; antagonistic relationship between political leaders from central to lower levels; weak representation of the views and key issues at the central government level; and financial constraints and limited capacity of human resources. The third category of governance problems is what this paper is going to focus being the major reason contributing to water scarcity in Pangani river basin. The paper addresses the following questions: What effects do these structures have on institutional policy design and discourse in the river basin management? Do the structures promoting or blocking institutional reforms? And how is the sustainability of the reforms ensured? The paper suggest on mainstreaming institutional set up of non-water sectors into the river basin model from central to local government level.

\section{Evolution of decentralization in Tanzania}

Tanzania has a two tier system of government that is the central government and local government. Local government is established both in urban and rural authorities. As demonstrated by PMO-RALG [16, 17] the first decade of independence from the period of 1961-1971, the central government aimed at establishing democratic administration system of bringing equitable development to all Tanzanians. The first period of decentralization started officially from 1972-1982 with the aim of promoting democratic system by transferring responsibilities and financial resources to deliver public services from central to local government. However in the process this led to collapse of local government authorities. Decentralization of central government through deconcentration system was applied to replace local government system and this resulted to merging both central and local government responsibilities. From the period of 1983-1995 reinstatement of local government authorities was considered mandatory to strengthen aspects of democracy and good governance. Enactment of local government Act of 1982 was approved and local authorities were re-established in both rural and urban areas. Local government reforms evolved from the period of 1996-2005 as a result of major obstacles in governance particularly related to financial constraints and limited human resource capacity. Decentralization by devolution principle is the major driver of the reforms and Obstacles to Development methodology is used as bottom-up planning approach at the local level. 


\section{The study area}

The Pangani river basin covers an area of 43,650 square kilometres and located in the North Eastern Tanzania (Figure 1). The river basin is distributed among four regions of Arusha, Kilimanjaro, Manyara and Tanga and the remaining part of 5\% is located in Kenya. The major catchments found in Pangani river basin include Kikuletwa, Ruvu, Mkomazi, Luengera and main stem of Pangani. It is estimated about 2.6 million people live in the river basin, agriculture being the major source of livelihood by $80 \%$. Irrigation is the major consumption of surface water in Pangani by $90 \%$ and is contributing to major conflicts in the

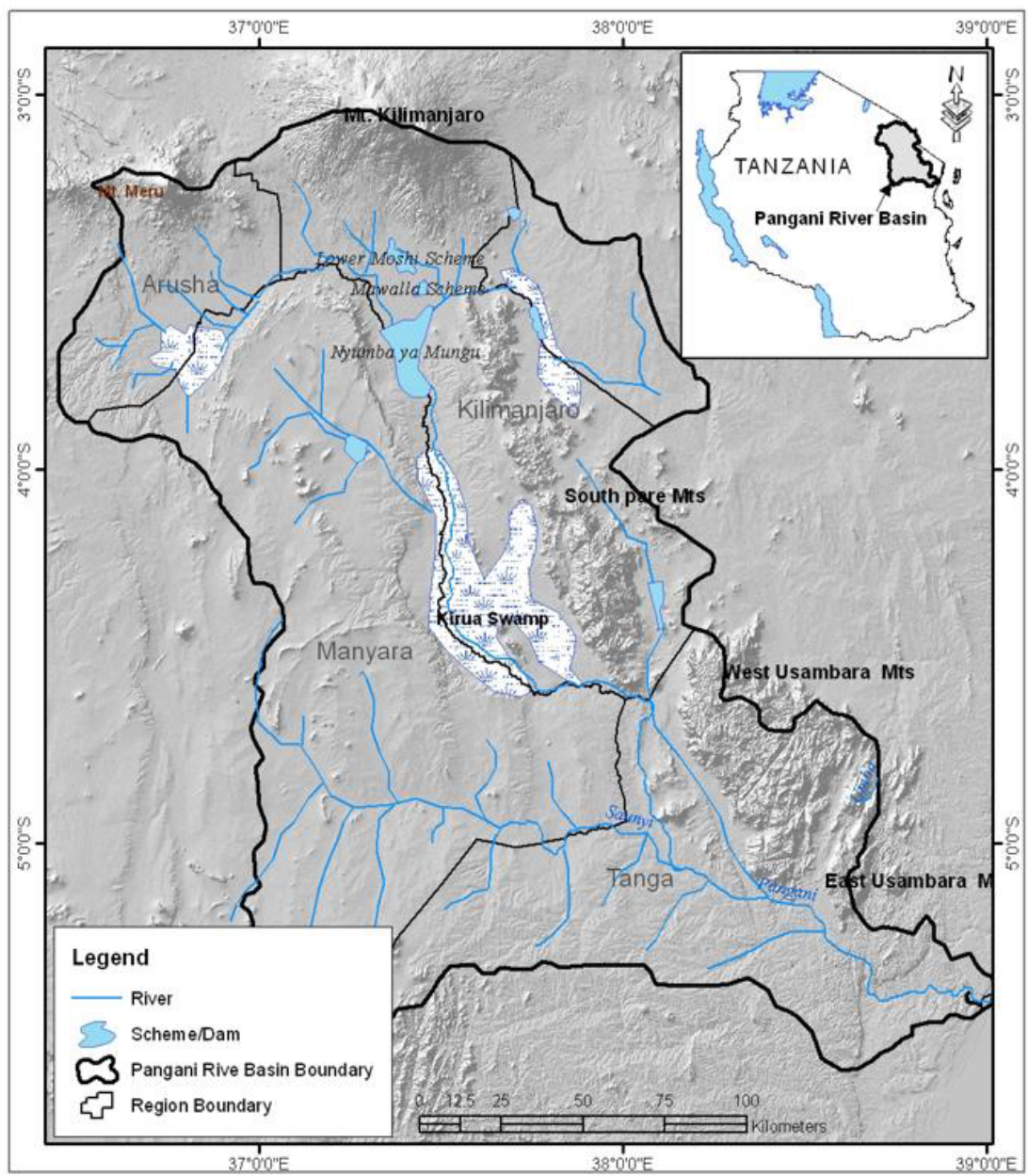

Figure 1: Map of Pangani river basin (showing location of study area). 
area due to water scarcity. The river is recorded to 500 square kilometres long (PBWO/IUCN [12]). The source of Pangani river originate from Mt. Kilimanjaro and Mt. Meru which form Kikuletwa and Ruvu rivers and drain its water in Pare and Usambara mountains and lastly emptying to Indian ocean.

\subsection{Lower Moshi irrigation scheme (LMIS)}

Lower Moshi Irrigation Scheme (LMIS) is located upstream in Moshi rural district, Kilimanjaro region. The scheme was developed specifically for supporting four villages of Mabogini, Chekereni, Oria and Rau covering 2300 hectares out of which 1,100 hectares was for paddy cultivation and the remaining 1,200 hectares for upland and perennial crops. LMIS is a modern improved scheme supported by Japanese International Cooperation Agency - JICA between the period of 1976 to 1990 under the Ministry of Agriculture. The Ministry is now expanding a new irrigation area to include two villages of Kaloleni and Mandaka mnono in the scheme. Water permit for the scheme is $1,900 \mathrm{~m}^{3} / \mathrm{sec}$ and annual water consumption is estimated to reach 65 million $\mathrm{m}^{3}$ and the water is abstracted from Rau river and Njoro springs. The scheme is managed by a local institution known as Lower Moshi Irrigators Association LOMIA and about 5,000 households benefit from the scheme.

\subsection{Mawalla scheme}

Mawalla scheme is located middle stream in Moshi rural district in Kilimanjaro region. The scheme covers 3 villages Oria, Ngasinyi and Mawalla. The scheme covers an area of 1426 hectares major economic activity being agriculture and livestock development. Paddy plantations compose the major part in the scheme and smaller part of mixed crops of maize, beans and vegetables. The agriculture production is mainly for food and cash crops. Abstraction of water in the scheme is from the major springs of Miwaleni with a granted water permit of $900 \mathrm{~m}^{3} / \mathrm{sec}$. Annual water consumption by the scheme is estimated to reach 28 million $\mathrm{m}^{3}$. The scheme is managed by a local institution representing the 3 villages namely Oria, Ngasinyi and Mawalla (ONGAMA). About 2,333 households are direct beneficiaries of the scheme.

\subsection{Nyumba ya Mungu dam (NYM)}

Nyumba ya Mungu dam (NYM) is distributed in 3 districts of Moshi rural, Simanjiro and Mwanga within Kilimanjaro region and covers 14,000 hectares and its construction was completed in 1966 for the purpose of hydropower generation and floods control. The storage capacity at NYM dam is estimated to reach $1140 \mathrm{~m}^{3}$ however reduced to $600 \mathrm{~m}^{3}$ during dry season with capacity to produce electricity of $8 \mathrm{MW}$. The dam is used to generate diversified source of livelihoods for fisheries and livestock sectors and about 20,000 households bordering the dam are direct beneficiaries. Beach management units (BMUs) as a local institution, is responsible in managing utilization of the dam by the local communities. 


\section{Methodology}

Pangani river basin is selected on the basis of the project area and is among the river basin in Tanzania currently faced with declining water flow situation amidst competing economic demands. The study was conducted in 3 man made wetlands namely Lower Moshi irrigation scheme, Mawalla scheme and Nyumba ya Mungu dam. Stakeholders were selected based on institutions responsible in utilizing water in selected wetlands from water and non-water sectors. Statistical analysis undertaken represent the sample characteristics and tap strengths and weaknesses of the structures in the specific wetlands in Pangani. They do not represent wetlands at the national level. A key informant interview was administered and data was collected from 50 personnel and local staff representing institutions from 7 Ministries from water and non-water sectors, Pangani Basin Water Office, Kilimanjaro region, Moshi and Mwanga districts and water users associations - Lower Moshi Irrigators Association, Oria, Ngasinyi and Mawalla association and Beach management units. Literature review was consulted from budgets reports, departmental reports and journal related articles. The interview process focused on governance, fiscal decentralization, water reforms, water permits, trade-offs for water allocation and cross-sectoral interests. The stakeholders were confined to government and local institutions from central government to the local level. Stakeholder consultation and engagement was also conducted.

As noted by (Kanbur [5]; White [28]; Ellis and Mdoe [3]) a combination of both qualitative and quantitative methods can help to solve problems that are associated with each type of method taken separately. In this study qualitative methods are used to address policy and institutional context of existing political structures and river basin organization while quantitative methods, the Net present value (NPV) was used to analyse sectors budget planning, revenues and expenditures. Network analysis was done between stakeholders as described by Schiffer [19] the objective being to identify stakeholders with high and low level of influence in water governance. The analysis came up with 3 groups; Central government, stahekolders with power, high influence and interest; Region, river basin and local government, stakeholders with defined mandate, interest and low influence; water user associations and local organizations, high ratio of dependency for water resources but with bounded mandate and no influence. The analysis reflect that as you approach down to the lower level of structure the influence is low and and in some cases non-existent.

\section{Results and discussion}

\subsection{Trade-offs for water resources: stakeholders' perspective}

The need to analyse trade-offs in Pangani river basin is mandatory in order to develop a range of potential scenarios and their consequences between sectors so as to come up with different development pathways and strategies for the future (PBWO [14]). Kashaigili et al. [7] demonstrate a case of Great Ruaha river, 
Tanzania and emphasize on the need for trade-offs analysis to reflect about balancing water demands between sectors of which requires a good understanding of the value of water in its different uses and the opportunity costs of water transfer from one sector to another. World Bank report [30] on 'Zambezi river basin Multi-sector investment opportunities analysis' attempt to design practical operational tools and how integrated water resource management can facilitate 'benefits of cooperation' in the region. Trade-offs analysis for hydropower production and irrigation were discussed.

Total water withdrawal in Tanzania as per year 2002 was estimated to be 5,142 million $\mathrm{m}^{3}$. From the total water, agriculture development accounts for 4,624 million $\mathrm{m}^{3}$ out of which irrigation consumes 4,417 million $\mathrm{m}^{3}(85 \%)$ and 207 million $\mathrm{m}^{3}$ (4\%) for livestock. 493 million $\mathrm{m}^{3}(10 \%)$ accounts for domestic sector and the remaining 25 million $\mathrm{m}^{3}(1 \%)$ is consumed by the industry sector. According to PBWO/IUCN [13] Mean Annual runoff (MAR) for Pangani river basin is estimated to be 1,540 million $\mathrm{m}^{3}$ out of which irrigation account for 550 million $\mathrm{m}^{3}$ equivalent to $13 \%$ of total irrigation water in the country. Storage capacity for hydropower generation is 1,140 million $\mathrm{m}^{3}$ equivalent to $71 \%$ of the mean annual runoff in Pangani. Water used for hydropower is non consumptive although a smaller portion of consumptive use is through evaporation and is released back to the environment. However for the case of Pangani the released water goes directly to Hale and new Pangani hydropower stations. PBWO/IUCN [13] indicate consumptive use demand in Pangani river basin is estimated to be 3,201 million $\mathrm{m}^{3}$ while water supplied account to 2,301 million $\mathrm{m}^{3}$ thus deficit is observed by 900 million $\mathrm{m}^{3}$.

\subsubsection{Central government: state centred approach}

The central government as the highest level within the political structure has significant role in strengthening governance among sector ministries however as a state is considered weak in capacity since approximately $50 \%$ of the budget is funded by Donors (URT [25]). The central government under the Ministry of finance has a key role to strengthen governance when it comes to budget allocation among sectors including water. Public expenditure review (PER) under the Medium term expenditure framework (MTEF) cross sector strategy is used to prioritize sectors requirements according to Poverty Reduction Strategy Paper (PRSP) objectives (Table 1). However as noted by URT [26] "there is a problem of integrating water sector resource requirements from regions and LGAs into the Ministry's input of the water sector to the budget guidelines". According to URT [25] from year 2004/05 to 2008/09 the budget allocated for water sector has been ranging from 309.1 to 397.6 billion Tshs equivalent of 3\% to $5 \%$ of the total budget and ranks the least in priority compared to other sectors. 
Table 1: Actual budget frame from year 2004/05 to 2008/09 (Tshs in Millions).

\begin{tabular}{|c|c|c|c|c|c|}
\hline & 2004/05 & 2005/06 & 2006/07 & 2007/08 & 2008/09 \\
\hline \multirow{4}{*}{$\begin{array}{l}\text { TOTAL REVENUE } \\
\text { Domestic revenue } \\
\text { LGAs own source } \\
\text { Foreign loans and } \\
\text { grants }\end{array}$} & $3,364,730$ & $4,131,946$ & $4,504,371$ & $5,269,042$ & $7,055,811$ \\
\hline & $1,773,709$ & $2,124,844$ & $2,739,022$ & $3,634,581$ & $4,240,074$ \\
\hline & NIL & NIL & NIL & NIL & NIL \\
\hline & $1,460,687$ & $1,635,968$ & $1,699,706$ & $2,348,203$ & $2,228,764$ \\
\hline \multirow{3}{*}{$\begin{array}{l}\text { Borrowing } \\
\text { Privatization proceeds } \\
\text { TOTAL } \\
\text { EXPENDITURE }\end{array}$} & 0 & 261,436 & 65,644 & $-713,742$ & 541,973 \\
\hline & 0 & 33,309 & 0 & 0 & 45,000 \\
\hline & $3,364,730$ & $4,131,946$ & $4,504,371$ & $5,269,042$ & $7,055,811$ \\
\hline \multirow{2}{*}{$\begin{array}{l}\text { Recurrent expenditure } \\
\text { Development } \\
\text { expenditure }\end{array}$} & $2,124,580$ & $2,788,580$ & $3,167,160$ & $3,458,070$ & $4,925,442$ \\
\hline & $1,240,150$ & $1,343,366$ & $1,337,211$ & $1,810,972$ & $2,130,368$ \\
\hline \multirow[t]{2}{*}{ Local } & 239,651 & 296,100 & 503,291 & 567,421 & 906,023 \\
\hline & $1,000,499$ & $1,047,266$ & 833,920 & $1,243,551$ & $1,224,345$ \\
\hline
\end{tabular}

Source: URT, Ministry of finance 2010.

\subsubsection{Regional administration and local government: bridging the gap}

Regional administration and local government act as a bridge between central government and communities. The case of Pangani wetlands presents different scenarios of managing water in the river basin (Table 2) and the study revealed the structure lacks self autonomy and widen the gap between regions, local government, Pangani Basin Water Office (PBWO) and communities. The first scenario presents a case of top-down approach from central government to lowest level in Lower Moshi Irrigation scheme (LMIS). Due to water scarcity the area for paddy cultivation is currently reduced by $67 \%$ from 1100 hectares to 360 hectares (Table 2) and the remaining area is now used for mixed crops instead of paddy. The scheme is also loosing revenue by more than $50 \%$ of the estimated revenue from surveyed area which is utilized below capacity. In comparison of revenue generated by LMIS and what is paid to PBWO is not proportional. PBWO gets $0.1 \%$ of the net profit generated from actual cultivation. Currently the Ministry of agriculture is expanding the scheme from 1100 hectares to 1500 hectares an increase of 400 hectares and do not take into account the issue of water availability. The second scenario presents a case of conflicting sectors between agriculture and livestock. Mawalla scheme located middle stream developed specifically for paddy cultivation is not improved scheme still using traditional furrows for water abstraction. The area is also utilized for livestock keepers and is used as a dry season refuge by pastoralists from neighbouring regions and districts. The actual cultivation is utilised below capacity by $58 \%$ (Table 2) of the total surveyed area due to water scarcity. The revenue generated is also reduced by $60 \%$ of the estimated total production from surveyed area. 
Conflicts between farmers and pastoralists are intese in the area. The third scenario presents a case of conflicting authority between central government and PBWO. Nyumba ya Mungu dam (NYM) was developed specifically for hydropower generation with capacity to produce 8MW however during dry season the production may drop by $50 \%$ due to water scarcity and over abstraction of water by upstream users. The dam is owned by PBWO but the authority to use the dam and revenue collection lies with central government and ministries of energy, livestock and fisheries. For the year 2009 NYM dam produced $34,633,670 \mathrm{Kwh}$ however the revenue generated goes directly to central government through Treasury. PBWO gets royalty of 200,000 T shs from Tanzania Electric Supplies Company (TANESCO) for using the dam and gets nothing from livestock and fisheries sectors (Table 2).

Table 2: $\quad$ Production by different stakeholders per annum (2009).

Tshs in equivalent to USD

\begin{tabular}{|c|c|c|c|c|c|}
\hline $\begin{array}{l}\text { Wetlands } \\
\text { Economic } \\
\text { Activity }\end{array}$ & $\begin{array}{c}\text { Surveyed } \\
\text { Area } \\
\text { ha/acre }\end{array}$ & $\begin{array}{c}\text { Cultivated } \\
\text { Area } \\
\text { ha/acre }\end{array}$ & $\begin{array}{c}\text { Revenue } \\
\text { surveyed } \\
\text { Area }\end{array}$ & $\begin{array}{c}\text { Revenue } \\
\text { Cultivated } \\
\text { area }\end{array}$ & $\begin{array}{l}\text { PBWO } \\
\text { Revenue }\end{array}$ \\
\hline \multirow{2}{*}{$\begin{array}{l}\text { LMIS } \\
\text { Paddy } \\
\text { plantations }\end{array}$} & \multirow{2}{*}{$\begin{array}{c}1100 \mathrm{ha} / \\
2717 \\
\text { acres }\end{array}$} & \multirow{2}{*}{$\begin{array}{c}360 \mathrm{ha} / \\
889 \text { acres }\end{array}$} & $5,434,000,000$ & $1,778,000,000$ & $1,900,000$ \\
\hline & & & $\$ 3,881,429$ & $\$ 1,270,000$ & $\$ 1,357$ \\
\hline \multirow{2}{*}{$\begin{array}{l}\text { Mawalla } \\
\text { Paddy } \\
\text { plantations }\end{array}$} & \multirow{3}{*}{$\begin{array}{c}1425 \mathrm{ha} / \\
3520 \\
\text { acres }\end{array}$} & \multirow{3}{*}{$\begin{array}{c}594 \mathrm{ha} / \\
1467 \\
\text { acres }\end{array}$} & $7,040,000,000$ & $2,934,000,000$ & 993,384 \\
\hline & & & $\$ 5,028,571$ & $\$ 2,095,714$ & $\$ 710$ \\
\hline Livestock & & & NIL & NIL & NIL \\
\hline \multirow{4}{*}{$\begin{array}{l}\text { NYM } \\
\text { dam } \\
\text { Electricity } \\
\text { Fisheries }\end{array}$} & \multirow[t]{5}{*}{14000 ha } & \multirow[t]{5}{*}{14000 ha } & $5,437,486,190$ & $5,437,486,190$ & 200,000 \\
\hline & & & $\$ 3,883,919$ & $\$ 3,883,919$ & $\$ 143$ \\
\hline & & & $1,151,542,832$ & $1,151,542,832$ & NIL \\
\hline & & & $\$ 822,531$ & $\$ 822,531$ & NIL \\
\hline Livestock & & & NIL & NIL & NIL \\
\hline
\end{tabular}

Source: Field data 2010.

LMIS - Lower Moshi Irrigation Scheme; NYM - Nyumba ya Mungu Dam; PBWO - Pangani Basin Water Office Net present value (NPV) = Paddy plantations: I acre $=30$ bags of rice $/ 3,000 \mathrm{kgs}$ (if well developed ), 1 bag of rice $=100 \mathrm{~kg} ; 1 \mathrm{~kg}=800 \mathrm{Tshs} ; 1$ acre costs of production (rice) $=1,400,000 \mathrm{shs}$; ; Revenue estimated for 2 seasons after deduction of production costs; Electricity revenue: 34,633,670 Kwh produced@Kwh 157 Tshs (Gross revenue). Exchange rate: $1 \mathrm{USD}=1,400$ shillings. 


\subsubsection{Water users association (WUAs)}

Decentralization advocates on devolution of authority, power and resources from central government to local level of governance. As discussed by Oakley [11] devolution of authority involves transferring policy formulation and implementation powers and resources from central to local levels. The study results revealed some of the policy directives approved by the central government impinge directly livelihoods of the people however WUAs as a local network the influence to higher levels of authority is tiny. According to water resource management Act No.11 [23] "the members of the association shall be villagers, institutions, companies, committees and authorities or any person natural or legal as may be users of water from sources located within the area of the responsibility of the association". However the Act did not take into consideration the issue of migration to the area which is a major problem in holding temporary members accountable. The study noted that most members in WUAs are passive and the reason being linkage between water resources management and existing economic activities is missing. The capacity by WUAs is lacking and poses a threat to Pangani river basin authority since as local institutions are responsible in collecting water fees on behalf of farmers and other users in the community.

\section{Benefit sharing: cross-sectoral collaboration}

Considerable efforts are now emerging in the field of benefit sharing for water between regions, states, countries and sectors. As proposed by (Philips et al. [15]; Turton [22]) a new direction of water resource management towards negotiation and sharing of benefits has to be explored. Water has economic value and should be regarded as economic good. From the case study of Pangani efficiency in water governance will only be sustainable if benefits are shared reflecting on utilization, allocation and type of economic activity between water and non-water sectors. River basin authority should be seen as one of the important bridge in the structure to facilitate institutions and stakeholders working in water and non-water sectors to reach desired ends as outlined in Tanzania development vision 2025. And for benefit sharing mechanism to take effect the need to institutionalize the structure is imperative. Central government has the lead role to play towards facilitating institutionalization of the structure. Decentralization process is blocking efforts of the institutions to work independently and ability to tap potential revenues generated from utilizing water. Water should not be seen as independent variable but rather dependent variable and economic activities performed by non-water sectors has a direct effect towards building foundation of good governance in the water sector. For the river basin authority to lead the road then ability to mobilize domestic funding by both sectors, strengthen capacity of water users associations and demonstrate value for water in promoting economic development and sustaining livelihoods is mandatory. 


\section{Conclusion and policy implications}

The system of decentralized political structures had the objective of shifting power and responsibilities from central to local government. This study has found the need to understand the relationship between the structure itself and the operations of different institutions within the structure. With particular to water resource management, the water sector faces serious challenges regarding to financial dimension of governance. Systematic planning and budgeting by local government is lacking and therefore cross-sectoral integration in the water sector is more of rhetorical rather than practical. From a practical policy perspective decentralization system within political structures should target more on setting grounds for mobilizing domestic sources of revenues. Still the role of central government under the Ministry of finance is crucial when it comes to budgeting and implementation of cross-sectoral plans. The case study of wetlands in Pangani river basin reveals the need to mainstreaming non-water sectors into water sector from central to local government. Benefit sharing mechanism pose as a promising departure point towards mainstreaming non-water sectors into the water sector and a source of domestic revenue mobilization. River basin organization sets a foundation stage for coordination and facilitation of benefit sharing mechanism between stakeholders from water and non-water sectors to be realised.

\section{References}

[1] Barham, E., Ecological boundaries as community boundaries. The politics of watershed. Society and Natural Resources, 14, pp. 181-191, 2001.

[2] Dixon, A.B. \& Wood, A.P., Wetland cultivation and hydrological management in Eastern Africa: Matching community and hydrological needs through sustainable wetland use. Natural Resources Forum, 27, pp. 117-129, 2003.

[3] Ellis, F. \& Mdoe, N., Rural Livelihoods and Poverty Reduction in Tanzania. World Development 40 (8), pp 1367-84, 2003.

[4] Kamukala, G. L., An overview and scope of Tanzania wetlands. In: Proceedings of a seminar on the wetlands of Tanzania. (Edited by Kamukala, G. L. and Crafter, S.A.), 27-29 November 1991, Morogoro, Tanzania. IUCN Gland Switzerland, pp 85- 93, 1993.

[5] Kanbur, R., Q-squared: Qualitative and Quantitative Methods of Poverty Appraisal. New Delhi. 145pp, 2001.

[6] Kangalawe, R. Y. M, \& Liwenga, E. T., Livelihoods in the wetlands of Kilombero valley in Tanzania. Physics and Chemistry of the Earth 30 (1116), pp 968-975, 2005.

[7] Kashaigili, J.J, Kadigi, R.M.J., Lankford, B. A., Mahoo, H. F., \& Mashauri, D.A. Environmental flows allocation in river basins: Exploring allocation challenges and options in the Great Ruaha River catchment in Tanzania. Physics and Chemistry of the Earth, 30 (11-16), pp 689-697, 2005. 
[8] Lein, H. \& Tagseth, M., Tanzanian water policy reforms-between principles and practical applications. Water policy 11, pp 203 - 220, 2009.

[9] Mbonile, M. J., Population, Migration and Water Conflicts in the Pangani River Basin, Tanzania. ECSP Report from Africa. Population, Health, Environment and Conflict. Issue 12, pp. 20-28, 2005.

[10] Mujwahuzi, M. R., (eds). Water use conflicts in the Pangani Basin. In Ngana, J. O. (eds). Water resources management in the Pangani River Basin: Challenges and opportunities. Dar es Salaam University Press, pp 128-137, 2001.

[11] Oakley, P., Projects with people - the practice of participation in Rural Development. Blackwells Cambridge, pp. 284, 1991.

[12] PBWO/IUCN. Pangani River System. State of the basin Report. PBWO, Moshi Tanzania and IUCN Eastern Africa Regional Program, Nairobi Kenya. www.iucn.org/dbtw-wpd/edocs/2007-002.pdf.

[13] PBWO/IUCN. Hydrology and system analysis volume 1 of 2: the hydrology of the pangani river basin, Report 1. Pangani River Basin Flow Assessment Initiative, Moshi, Tanzania, pp 62, 2006.

[14] PBWO/IUCN. Socio-economic baseline assessment report: The role of river systems in household livelihoods. Pangani river basin flow assessment, Moshi, Tanzania pp 58, 2007.

[15] Philips, D., Daoudy, M., Ojendal, J., Turton, A.R. \& McCaffrey, S. Transboundary water cooperation as a tool for conflict prevention and for broader benefit-sharing. Ministry for Foreign Affairs, Stockholm, Sweden, 2006.

[16] PMO-RALG, Prime Minister's Office Regional Administration and Local Government. Www.pmoralg.go.tz/documents_storage/2007-4-21-3-2-22historical.pdf.

[17] PMO-RALG, Prime Minister's Office Regional Administration and Local Government. Www.pmoralg.go.tz/documents_storage/2009/-12-12-10-434_o\&od_icr.pdf.

[18] Ramsar, www.ramsar.org

[19] Schiffer, E. www.uni-hohenheim.de/igm

[20] Southgate, C., \& Hulme, D., The scramble for wetland in Southern Kenya. In: Woodhouse, P., Bernstein, H., Hulme, D., (Eds) African enclosures? The social dynamics of wetlands in Drylands. James Curray, Oxford, 2000.

[21] Turpie, J., Y. Ngaga, Y. \& Karanja, F., Catchment Ecosystems and Downstream Water: The Value of Water Resources in the Pangani Basin, Tanzania. Lao PDR. IUCN Water, Nature and Economics Technical Paper No. 7. IUCN, The World Conservation Union, Ecosystems and Livelihoods Group Asia. 99 pp, 2005.

[22] Turton, A. R. The political aspects of institutional development in the water sector: South Africa and its international river basins. D. Phil. thesis. Department of Political Science, University of Pretoria, 2003.

[23] URT. Water resources management Act No. 11. United Republic of Tanzania, pp 353-424, 2009. 
[24] URT. National water policy. Ministry of Water, United Republic of Tanzania, pp 88, 2002.

[25] URT. Ministry of Finance, Budget speech on the estimates of government revenue and expenditure for the financial year 2010/2011, Dar es salaam, Tanzania, pp 80, 2010.

[26] URT. Ministry of Finance. Public Expenditure Review. Annual Consultative meeting. Medium Term Expenditure Framework - MTEF, Cross sector strategy, Dar es salaam, Tanzania, pp 26 (2004)

[27] URT. National Wetlands Management Strategy. Ministry of Natural Resources and Tourism. Dar es salaam, Tanzania. Final Draft. pp 48, 2007.

[28] White, H., Combining quantitative and qualitative approaches in poverty analysis. World Development 30(3), pp. 511-522, 2002.

[29] World Bank. River Basin Management and Smallholder Irrigation Improvement Project (RBMSIIP). Implementation completion and results report. Www.worldbank.org/external/projects/main?page $\mathrm{PK}=51351038$ \&piPK=51351152\&theSitePK=40941\&projid $=\mathrm{P} 038570$

[30] World bank. Zambezi river basin Multi sector investment opportunities analysis. Www.siteresources.worldbank.org/INTAFRICA/Resources/ Zambezi_MSIOA_-_Vol_1___Summary-Report.pdf 